\title{
Developing Scale for Determining the Social Participation Skills for Children and Analyzing Its Psychometric Characteristics
}

\author{
Osman Samanc1 ${ }^{1}$, Ebru Ocakc1 ${ }^{1} \&$ İsmail Seçer ${ }^{1}$ \\ ${ }^{1}$ Kazım Karabekir Faculty of Education, Atatürk University, Erzurum, Turkey \\ Correspondence: Ebru Ocakc1, Kazım Karabekir Faculty of Education, Atatürk University, Erzurum, Turkey. \\ Tel: 90-442-231-4473. E-mail: ebru.ocakci@atauni.edu.tr
}

Received: January 4, 2018

Accepted: March 19, $2018 \quad$ Online Published: May 29, 2018

doi:10.5539/ies.v11n6p92

URL: https://doi.org/10.5539/ies.v11n6p92

\begin{abstract}
The purpose of this research is to conduct validity and reliability studies of the Scale for the Determining Social Participation for Children, developed to measure social participation skills of children aged 7-10 years. During the development of the scale, pilot schemes, validity analyzes, and reliability analyzes were conducted. In this context, the research was carried out with a total of 472 elementary school students in the ages of 7-10 years using the descriptive survey model. Exploratory and confirmatory factor analyses were performed to examine the factor structure of the scale and it was determined that the scale had a structure consisting of 16 items and one dimension and that this model had a good level of model fit. In order to examine the reliability of the scale, internal consistency and split-half reliability analyzes were performed and it was found that the scale had sufficient reliability. It can be said that the Scale for the Determining Social Participation for Children is a reliable and valid measurement tool that can be used to measure the social participation skills of students aged 7-10 years.
\end{abstract}

Keywords: social participation, social skills, development of scale

\section{Introduction}

As a social being, the individual is expected to acquire some skills that will make it easier for him to accommodate with the society he lives in. Acquisition of these skills, which are expressed as social skills, is possible with the fact that the individual enters social environments and interact with others. Social participation skills can be defined as the active participation of the individual in social life and developing himself in this direction.

Social skill is developing appropriate behaviors by understanding the thoughts, emotions and behaviors of the individual himself and others through different interactions (Çubukçu \& Gültekin, 2006). Social skills enable the individual to interact positively with other individuals in the community he lives in. For this reason, individuals with adequate social skills can easily interact with their surroundings, receive information, and leave positive impressions at the end of the interaction. Social skills include learned behaviors that depend on the social norms of the community in which the individuals live and are used by the individuals for a specific purpose (Stanley, 2010).

Social participation, which has a prominent place in social skills, is defined as the participation of the individuals in social activities by themselves or with a group (Adler \& Goggin, 2005). In a more general sense, social participation includes formal processes such as participation in a learning activity, as well as informal processes related to the social environment such as participation in division of labor within the family, participation in peer relationship, participation in relative and neighborhood relationship. Social participation skills aim to encourage children to participate in social, cultural, artistic and sports activities both in the school environment and in the social life, thereby improving self-confidence and sense of responsibility. Thus, social participation skills are included in the curriculums of Social Studies lesson and Life Sciences lesson within formal education in Turkey.

In the study by Kovalainen and Kumpulainen (2007) in which the structure of participation was analyzed based on the interaction between the teachers and the students, it determined that the classroom interaction manners mediate the learning opportunities in the classroom. In a study by Krantz (1982), it was found that children with a high level social participation are aware of friendship structures of their peers and are perceived as more popular by their peers. Altınok (2012) found that the students who participate in social activities are more sensitive to social problems than those who do not. Evaluating the related studies, it is seen that the students who display social participation behaviors are more aware of the learning opportunities and the issues related to social environment. 
This reveals the importance of social participation once more.

When the literature is reviewed, it is seen that there are studies related to the social participation skills of the special needs kids (Avramidis, 2013; Bossaert, Boer, Frostad, Pijl, \& Petry, 2015; Garrote, 2017; Schwab, Gebhardt, Krammer, \& Gasteiger-Klicpera, 2015; Tsao, Odom, Buysse, Skinner, West, \& Vitztum-Komanecki, 2008). According to the results of these studies, it is determined that the special needs kids display social participation behaviors less than their normal-developed peers and they made friendship with their peers.

According to Bacanll (2014), it is possible to determine the social skills of individuals by behavioral measurement methods. There are various techniques and scales used to measure social skills. One of these techniques, self-report measures, is based on self-reporting through the scale provided. When the measurement tools developed on social skills are examined in the literature, measurement tools developed by Riggio (1989), Kocayörük (2000), Kabakçı and Korkut-Owen (2010) attracted our notice. When the studies on social participation skills are examined, the study of Parten (1932) in which he studies the social participation skills of pre-school children with one-minute sampling observation method during free play hours draws attention. It was seen that a picture sociometric technique developed by Marshall and McCandless (1957) was also used related to the social participation skills of the students. The Social Participation Questionnaire developed by Koster, Minnaert, Nakken, Pijl, and Houten (2011) and Child and Adolescent Scale of Participation developed by Bedell (2009) are among the measurement tools which compel attention in this field.

It is striking that the students are generally evaluated by their parents, teachers, peers or the researchers in the studies that aimed to determine the social participation skills. In this context, it was thought that there is a need for a tool to measure social participation skills which is reliable and valid based on self-report. With reference to this need, the aim of this research is to develop a measurement instrument that can be used to determine the social participation skills of children aged 7-10 years. It is thought that this measurement tool which is desired to be developed will contribute to the field as determining the social participation skills of the children, will shed light on the measurement tools for social skills to be developed after that, and will partly meet the need for a measurement tool which is reliable and valid for social participation ability.

\section{Method}

\subsection{Research Model}

This study was conducted in descriptive survey model. In descriptive survey model, data is collected to find answers to the research questions about the views of the individuals on a subject. Descriptive survey research is a method used to obtain information about the attitudes, beliefs, values, behaviors, thoughts, habits, desires and ideas of a particular community. Descriptive survey studies can be carried out on a group of selected samples from the analyzed community, as well as on the whole of the group studied, that is to say, to the population. A written measuring instrument which includes the questions or interview method can be used to obtain the data (Gay, Mills, \& Airasian, 2012; McMillen \& Schumacher, 2010).

In this study, a descriptive survey model was chosen to determine the social participation skills of children aged 7-10 years and, in this context, the Scale for Determining Social Participation Skills for Children was developed, and reliability and validity analyzes were conducted.

\subsection{Study Group}

During the development of the scale, different sampling groups were used for each stage. In this context, two different pilot scheme groups $(\mathrm{N}=100)$, explanatory and confirmatory factor analysis groups $(\mathrm{N}=310)$ and reliability analyses groups $(\mathrm{N}=62)$ were formed. During the development of the scale, the study was carried out with 472 primary school students aged 7-10. Detailed information about the study groups with which construct validity and reliability analyses were done is indicated in Table 1.

Table 1. Distribution of the construct validity and reliability analyzes study groups according to gender

\begin{tabular}{lccc}
\hline & Gender & $\mathrm{N}$ & $\%$ \\
\hline \multirow{3}{*}{ Construct Validity (EFA and CFA) } & Female & 159 & 51.3 \\
& Male & 151 & 48.7 \\
& Total & 310 & 100 \\
\hline \multirow{3}{*}{ Reliability Analyses } & Female & 33 & 53.2 \\
& Male & 29 & 46.8 \\
& Total & 62 & 100 \\
\hline
\end{tabular}




\subsection{Preparation of the Data Collection Tool}

To create item pool for the Scale for Determining Social Participation Skills for Children, literature review was done related to social skills and social participation skills. In addition, semi-structured interviews with classroom teachers were held in a primary school in Erzurum province and opinions were taken on behaviors indicating social participation skills. The data obtained from these interviews and the related literature was analyzed by content analysis technique and the first item pool consisting of 65 items was formed as a result of analysis.

After the creation of the item pool, the field psychology, child development and scale development experts were asked to assess the scale draft in terms of face validity, content validity and suitability; Turkish language experts were asked in order to assess understandability of the scale in terms of language. In the direction of the feedbacks received from the experts, 14 items were excluded from the scale as they were determined to be not appropriate for scale structure and scope of the subject. In the direction of the feedbacks, necessary corrections were made in the statements in the scale and the scale consisting of 51 items was given the first shape. In order to determine the level of participation in the statements on the scale, a 4-point likert type rating of "Never (1)", "Occasional (2)", "Frequently (3)", "Always (4)" is preferred. that the age group towards which the scale was addressed was 7-10 was considered in the preference of the 4-point likert scale.

\subsection{Data Analysis and the Procedure}

Two different pilot schemes were conducted in order to analyze the item fit of the Scale for Determining the Social Participation Skills for Children. The first form of the scale consisting of 51 items was first examined on a study group of 50 people; following the first analysis, item fit indices of the scale were re-analyzed on a new group of 50-person with the corrections made. Since it was observed that the total correlation values of 26 items were insufficient in both examination processes, it was decided to remove them from the scale form by consulting the opinions of field and measurements experts. After the items extracted, the opinions of field experts were asked for reassessing the content validity of the scale and the feedback was taken that there was no problem within this scope.

With the latest form of the scale consisting of 25 items, construct validity study was conducted on a 310-person group and explanatory and confirmatory factor analyses were done accordingly. The blank items (up to most $2 \%$ ) in the obtained data were filled with arithmetic mean at an acceptable rate. In the analysis of the latent structure of the scale, explanatory factor analysis (EFA) was used, and confirmatory factor analysis (DFA) was used in the analysis of the model data fit of the scale. The results of the EFA showed that the scale has a one-factor structure. The model data fit of the one-factor structure obtained through EFA was analyzed with CFA and it was determined that the scale has an appropriate level of model fit. After completing validity analysis, the reliability studies of the scale were done with a new sample group consisting of 62 people. For this purpose, internal consistency coefficient and half-split reliability of the Scale for Determining the Social Participation Skills for Children were analyzed. During the analysis, SPSS 22.00 for explanatory factor analysis and LISREL 9.2 for confirmatory factor analysis were used.

\section{Results}

\subsection{Results Related to Construct Validity of the Scale for Determining the Social Participation Skills for Children}

EFA was used in the analysis of the latent structure of the scale, and CFA was used in the analysis of the model data fit of the scale. The findings obtained from the analyses were examined under two titles:

\subsubsection{Results Related to Explanatory Factor Analysis}

$\mathrm{KMO}$ and Barlett tests were done in order to determine the fit indices of the data obtained from 310-person group through the Scale for Determining the Social Participation Skills for Children for factor analysis. The KMO test is a measurement technique used for the adequacy of the sample and the approximation of the reached value to 1 is considered as sufficient sample size (Seçer, 2015). Pallant (2001) stated that the KMO value should be .60 and above. According to Yurtkoru and Çinko (2008), .80 and above KMO value is a perfect fit.

As a result of the tests, KMO value was found to be .870 and Barlett $\chi 2$ test value was found to be 1848,178 $(\mathrm{p}<.001)$. That the KMO value is higher than .60 and also Barlett test's results were significant were assessed that the data was appropriate for factor analysis. After determining the fit indices of the data set, EFA was conducted and during EFA, it was paid attention that eigenvalues of the sub-dimensions that would be in the scale were at least 1.00 and the item factor loads were at least .30 (Büyüköztürk, 2014; Seçer, 2015). As a result of EFA, a one-factor structure consisting of 16 items was obtained. Within this scope, it was decided to exclude a total of 9 items from the scale which were determined to have inadequate factor load values. After the items that were excluded from the scale, it was determined that the one-factor structure of the scale explained $34 \%$ of the total 
variance. According to Büyüköztürk (2014), that the variance explained on single factor scales is $30 \%$ and above is sufficient. In this direction, it was evaluated that the value obtained in EFA is sufficient to decide the factor of the scale. The findings obtained related to exploratory factor analysis is given in Table 2.

Table 2. Results related to explanatory factor analysis

\begin{tabular}{lcc}
\hline Item No & Item Factor loading & Total Item Correlation \\
\hline M1 & .71 & .37 \\
M2 & .56 & .41 \\
M3 & .55 & .44 \\
M6 & .61 & .45 \\
M7 & .45 & .35 \\
M8 & .47 & .32 \\
M10 & .52 & .33 \\
M12 & .62 & .42 \\
M14 & .47 & .41 \\
M15 & .55 & .43 \\
M18 & .68 & .45 \\
M20 & .60 & .52 \\
M22 & .58 & .50 \\
M23 & .55 & .48 \\
M24 & .50 & .39 \\
M25 & .49 & .51 \\
Explained variance & $\% 34$ & \\
\hline
\end{tabular}

On analyzing the Table 2, it is seen that the item factor loadings and item total correlation values in the single factor structure of the scale are sufficient and that this single factor structure explains $34 \%$ of the total variance.

\subsubsection{Results Related to the Confirmatory Factor Analysis}

The model fit indices of the 16-item and one-factor structure of the Scale for Determining the Social Participation Skills for Children obtained as a result of EFA were analyzed with CFA and the obtained findings are indicated in Figure 1.

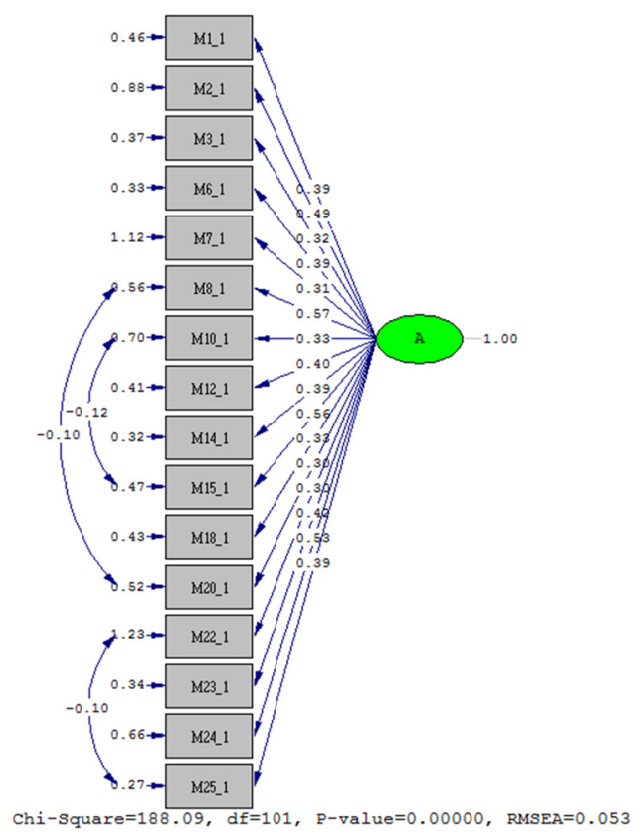

Figure 1. Confirmatory factor analysis results related to the scale for determining the social participation skills for children 
In CFA in which the model data fit of the scale which has one dimension and 16 items was analyzed, it was observed that some of the indexes weren't at a good fit level in the first stage and modification was needed. In this context, modification process was done between the items 8 and 20, 10 and 15 and 22 and 25 in the direction of modification recommendations. It was seen that the scale gave good fit after the modification process. In this direction, it was determined that the model data fit of the scale was provided on analyzing the model fit indices of the scale after the modification process $\left(\mathrm{X}^{2}=188.09, \mathrm{sd}=101, \mathrm{p}=.00, \mathrm{X}^{2}=1.86\right)$. Values for fit indices were found to be RMSEA $=.053$, RMR $=.041$, NFI $=.92$, NNFI $=.96$, CFI $=.96$, IFI $=.96$, RFI $=.91$, AGFI $=.90$, GFI $=.93$. On analyzing the findings obtained as a result of CFA, it was determined that the one-factor structure of the scale consisting of 16 items gave good fitness and construct validity was provided (Marcoulides \& Schumacher, 2001).

3.2 Results related to the Reliability Analysis of the Scale for Determining the Social Participation Skills for Children

In the reliability analysis of the Scale for Determining the Social Participation Skills for Children, internal consistency and split-half reliability analyses were done. The findings obtained through the analyses are indicated in Table 3.

Table 3. Internal consistency and split-half reliability test results related to scale for determining social participation skills for children

\begin{tabular}{ccc}
\hline & Internal Consistency & Split-Half Reliability \\
\hline Social Participation & .80 & .76 \\
\hline
\end{tabular}

In the cases that the reliability coefficient is above .70, the measurement tool is accepted to be (Fraenkel, Wallen, \& Hyun, 2012; Landis \& Koch, 1977; Sipahi, Yurtkoru, \& Çinko, 2008). It can be said that the scale has internal consistency and is reliable as the internal consistency coefficients obtained for the one-factor structure of the scale in all internal consistency and split-half reliability analyses done to for the reliability analysis of the Scale for Determining the Social Participation Skills for Children are at good levels. When these results obtained from the reliability and validity analyzes are evaluated, it can be said that the Scale for Determining the Social Participation Skills for Children is a reliable and valid measuring tool that can be used in the process of examining social participation skills of children aged 7-10.

\section{Discussion}

Social participation skill is a skill that involves actively participating in educational processes, friendship relations, social relations and voluntary services, and aiming to be informed of and sensitive about himself and the society in which the individual lives. When social participation skills are considered in the lives of individuals, it is considered to be important to examine this skill from childhood. In this sense, it is considered that there is a need for a measuring instrument that is reliable and valid to determine the social participation skills of children directly. From this need, the Scale for Determining Social Participation Skills for Children was developed, and validity and reliability analyses were conducted.

The scale obtained as a result of validity and reliability analysis is very practical and useful. Therefore, it is possible for classroom teachers who do not have special education or information about psychological tests to use the scale to determine the students' social participation skills. It is thought that the Scale for the Determination of the Social Participation of Children Scale is a measurement tool that can be used by different field researchers as well as class teachers who are interested in the participation of the students in the social life and who work on social participation skills of the. When the studies on social participation were evaluated, it was seen that the studies carried out with observation method by Parten (1932) and Goldman (1981) provided important contributions to the field. The study conducted by Sömen (2016) with observation and interview methods is also important in terms of examining how the social sciences teachers bring social skills in the students. Child and Adolescent Scale of Participation by Bedell (2009) and The Social Participation Questionnaire by Koster, Minnaert, Nakken, Pijl, and Houten (2011) are also among the measurement tool that contributed to the field in terms of social participation of the special needs kids. In these studies, it is seen that students' social participation skills are assessed by their parents, teachers, peers or researchers. Unlike these studies, the developed the Scale for Determining Social Participation Skills for Children is based on the self-report of the students. When evaluated under the framework of the mixed method, the use of scale together with observation and interview methods will provide a more holistic understanding of social participation skills.

The general information to note about the use of the scale is as follows: The Scale for Determining Social 
Participation Skills for Children consists of 16 items and one dimension. Behavioral sentences that express social participation skills are included in the scale items. The scale, which is prepared as a four-point likert type, has the options of "Never," "Occasional," "Frequent" and "Always" in order to indicate the frequency with which students perform these behaviors. There is no item on the scale that contains negative statements and must be reversed. Each item in the scale takes a value between 1 and 4 . Therefore, the points that can be taken from the scale range from 16 to 64 . The high scores to be obtained on the scale indicates the high level of social participation.

The limitations of this research on the development of the Scale for Determining the Social Participation Skills for Children have also been assessed. Validity and reliability analyses of the scale were conducted only with primary school students between 7-10 years old, who were studying in Erzurum city center. For this reason, the lack of validity and reliability studies in primary school out of Erzurum appears to be the limit of the scale. Considering that social participation skills have a major place in every period of life of the individual, the fact that the studies of validity and reliability are not carried out on children over 10 years of age is accepted to be another limitation of the scale. In future studies, it may be advisable to reconstruct the validity and reliability studies of the Scale for Determining the Social Participation Skills for Children to include students from different regions of Turkey and older age groups.

\section{References}

Adler, R. P., \& Goggin, J. (2005). What do we mean by civic engagement? Journal of Transformative Education, 3(3), 236-253. https://doi.org/10.1177/1541344605276792

Altınok, A. (2012). Sosyal katılım faaliyetlerinin 12-14 yaş grubu öğrencilerinin sosyal problemlere olan duyarlılıklarına etkisi. Yüksek lisans tezi. Aksaray Üniversitesi Sosyal Bilimler Enstitüsü, Aksaray. Retrieved from https://tez.yok.gov.tr/

Avramidis, E. (2013). Self-concept, social position and social participation of pupils with SEN in mainstream primary schools. Research Papers in Education, 28(4), 421-442. https://doi.org/10.1080/02671522.2012.673006

Bacanlı, H. (2014). Sosyal beceri eğitimi. Ankara: Pegem Akademi Yayıncılık.

Bedell, G. (2009). Further validation of Child and Adolescent Scale of Participation. Developmental Neurorehalibilitation, 12(5), 342-351. https://doi.org/10.3109/17518420903087277

Bossaert, G., Boer, A. A., Frostad, P., Pijl, S. J., \& Petry, K. (2015). Social participation of students with special educational needs in different educational systems. Irish Educational Studies, 34(1), 43-54. https://doi.org/10.1080/03323315.2015.1010703

Büyüköztürk, Ş. (2014). Sosyal bilimler için veri analizi el kitabı. Ankara: Pegem Akademi Yayıncılık.

Çubukçu Z. \& Gültekin, M. (2006). İlköğretimde öğrencilere kazandırılması gereken sosyal beceriler. Bilig/Türk Dünyast Sosyal Bilimler Dergisi, 37, 155-174. Retrieved from http://dergipark.gov.tr/download/article-file/234388

Fraenkel, J. R., Wallen, N. E., \& Hyun, H. H. (2012). How to design and evaluate research in education. London: McGraw Hill.

Garrote, A. (2017). The relationship between social participation and social skills of pupils with an intellectual disability: a study in inclusive classrooms. Frontline Learning Research, 5(1), 1-15. https://doi.org/10.14786/flr.v5i1.266

Gay, L. R., Mills, G. E., \& Airasian, P. (2012). Educational research: Competencies for analysis and applications. London: Pearson.

Goldman, J. A. (1981). Social participation of preschool children in same-versus mixed-age groups. Society for Research in Child Development, 52(2), 644-650. https://doi.org/10.2307/1129185

Kabakçı, Ö. F., \& Korkut-Owen, F. (2010). Sosyal duygusal öğrenme becerileri ölçeği geliştirme çalışması. Eğitim ve Bilim, 35(157), 152-166. Retrieved from http://egitimvebilim.ted.org.tr/index.php/EB/article/view/293

Kocayörük, A. (2000). İlköğretim Öğrencilerinin Sosyal Becerilerini Geliştirmede Dramanın Etkisi. Yüksek lisans tezi. Ankara Üniversitesi Sosyal Bilimler Enstitüsü, Ankara. Retrieved from https://tez.yok.gov.tr/

Koster, M., Minnaert, A. E. M. G., Nakken, H., Pijl, S. J., \& Houten, E. J. V. (2011). Assessing social participation of students with special needs in inclusive education: validation of the Social Participation Questionnaire. 
https://doi.org/10.1177/0734282910384065

Kovalainen, M., \& Kumpulainen, K. (2007). The social construction of participation in an elementary classroom community. International Journal of Educational Research, 46, 141-158. https://doi.org/10.1016/j.ijer.2007.09.011

Krantz, M. (1982). Sociometric awareness, social participation, and perceived popularity in preschool children. Society for Research in Child Development, 53(2), 376-379. https://doi.org/10.2307/1128979

Landis, J. R., \& Koch, G. G. (1977). The measurement of observer agreement for categorical data. Biometrics, 33(1), 159-174. https://doi.org/10.2307/2529310

Marcoulides, G., \& Schumacher, R.(2001). New developments and techniques in structural equation modeling. London: Lawrence Erlbaum Associates, Publishers.

Marshall, H. R., \& McCandless B. R. (1957). A study in prediction of social behavior preschool children. Society for Research in Child Development, 28(2), 149-159. https://doi.org/10.2307/1125877

McMillan, J. H., \& Schumacher, S. (2010). Research in education: Evidence-based inquiry. London: Pearson.

Pallant, J. (2001). SPSS Survival Manual. Maidenhead, PA: Open University Press.

Parten, M. B. (1932). Social participation among pre-school children. Journal of Abnormal and Social Psychology, 27(3), 243-269. https://doi.org/10.1037/h0074524

Riggio, R. E. (1989). Manual for the Social Skills Inventory: Research Edition. Palo Alto, CA: Consulting Psychologists Press.

Schwab, S., Gebhardt, M., Krammer, M., \& Gasteiger-Klicpera, B. (2015). Linking self-rated social inclusion to social behaviour. An empirical study of students with and without special education needs in secondary schools. European Journal of Special Needs Education, 30(1), 1-14. https://doi.org/10.1080/08856257.2014.933550

Seçer, İ. (2015). Psikolojik test gelişstirme ve uyarlama süreci: SPSS ve LISREL uygulamaları. Ankara: Anı Yayıncilık.

Sipahi, B., Yurtkoru, E. S. \& Çinko, M. (2008). Sosyal bilimlerde SPSS'le veri analizi. İstanbul: Beta Basım Yayım Dağıtım.

Sömen, T. (2016). Sosyal bilgiler öğretmenlerinin ögrencilere sosyal katılım becerisi kazandırma durumları. Doktora tezi. Atatürk Üniversitesi Eğitim Bilimleri Enstitüsü, Erzurum. Retrieved from https://tez.yok.gov.tr/

Stanley, M. (2010). Çocuk ve beceri. İstanbul: Ekinoks Yayıncılık.

Tsao, L., Odom, S. L., Buysse, V., Skinner, M., West, T., \& Vitztum-Komanecki, J. (2008). Social participation of children with disabilities in inclusive preschool programs: program typology and ecological features. Exceptionality, 16, 125-140. https://doi.org/10.1080/09362830802198203

\section{Copyrights}

Copyright for this article is retained by the author(s), with first publication rights granted to the journal.

This is an open-access article distributed under the terms and conditions of the Creative Commons Attribution license (http://creativecommons.org/licenses/by/4.0/). 